\title{
Phytotechnical characteristics of common bean under different nitrogen levels during seeding and sidedressing in the rainy season in Northern Minas Gerais
}

\author{
Características fitotécnicas do feijoeiro sob doses de nitrogênio em \\ semeadura e cobertura na safra das águas no Norte de Minas Gerais
}

\author{
Rodinei Facco Pegoraro ${ }^{1 *}$; Rodrigo Cardozo Coutinho ${ }^{2}$; \\ Neiva Maria Batista Vieira ${ }^{3}$; Marcos Koti Kondo ${ }^{1}$; Dário Oliveira ${ }^{2}$
}

\begin{abstract}
Few studies have focused on the appropriate management of nitrogen $(\mathrm{N})$ levels at the seeding and sidedressing phases to increase the grain yield of common bean in the semiarid region of Brazil, despite the high demand for $\mathrm{N}$ by the bean crop. The present study aimed to evaluate the agronomic characteristics of common bean grown during the rainy season following fertilization with different $\mathrm{N}$ levels at seeding and sidedressing. A $4 \times 4$ factorial structure was used, corresponding to four $\mathrm{N}$ levels at seeding $\left(0,40,80\right.$ and $\left.120 \mathrm{~kg} \mathrm{ha}^{-1}\right)$ and four $\mathrm{N}$ levels at sidedressing $\left(0,40,80\right.$ and $\left.120 \mathrm{~kg} \mathrm{ha}^{-1}\right)$. The experimental design consisted of randomized blocks with three replicates. The study was conducted in a dystrophic Red Latosol under conventional soil tillage. The 'Pérola' cultivar was sown in plots formed of six rows (each $5 \mathrm{~m}$ long), spaced $0.5 \mathrm{~m}$ apart, using the four central rows, totaling $10 \mathrm{~m}^{2}$ of useful area. The following parameters were evaluated: final stand, number of pods per plant, number of grains per pod, 100-grain weight and yield. The $\mathrm{N}$ levels at seeding increased the number of pods per plant, and sidedressing fertilization using $83.33 \mathrm{~kg} \mathrm{ha}^{-1} \mathrm{~N}$ yielded the highest 100 -grain weight. The maximum yield (MTE; $3.092 \mathrm{~kg} \mathrm{ha}^{-1}$ ) was found when using $62.4 \mathrm{~kg} \mathrm{ha}^{-1} \mathrm{~N}$ at seeding and $61.9 \mathrm{~kg} \mathrm{ha}^{-1} \mathrm{~N}$ at sidedressing, and the maximum economic efficiency (MEE) was found when using $60.3 \mathrm{~kg} \mathrm{ha}^{-1} \mathrm{~N}$ at seeding and $59.5 \mathrm{~kg} \mathrm{ha}^{-1} \mathrm{~N}$ at sidedressing, indicating the need for split $\mathrm{N}$ fertilization of common bean during the rainy season in the northern region of Minas Gerais State.
\end{abstract}

Key words: Phaseolus vulgaris L, 100-grain weight, yield

\section{Resumo}

\begin{abstract}
Apesar da elevada demanda de nitrogênio pela cultura do feijoeiro, no Brasil são relatados poucos estudos voltados para o manejo adequado de doses de $\mathrm{N}$ em semeadura e cobertura no aumento do rendimento de grãos do feijoeiro comum para a região semiárida. O presente estudo objetivou avaliar as características fitotécnicas do feijoeiro após a adição de doses de nitrogênio em semeadura e cobertura na safra das águas. Foi utilizado o esquema fatorial $4 \mathrm{x} 4$, correspondente a quatro doses de $\mathrm{N}$ na semeadura $\left(0,40,80,120 \mathrm{~kg} \mathrm{ha}^{-1}\right)$ e quatro doses de $\mathrm{N}$ em cobertura $\left(0,40,80,120 \mathrm{~kg} \mathrm{ha}^{-1}\right)$. O delineamento experimental utilizado foi de blocos casualizados, com três repetições. O estudo foi conduzido em Latossolo Vermelho eutrófico sob preparo convencional do solo. A cultivar Pérola foi semeada em parcelas compostas por 6 linhas com $5 \mathrm{~m}$ de comprimento, e espaçadas por 0,5 $\mathrm{m}$ entre linhas, destas,
\end{abstract}

\footnotetext{
${ }^{1}$ Profs. da Universidade Estadual de Montes Claros, UNIMONTES, Janaúba, MG, Brasil. E-mail: rodinei_pegoraro@yahoo.com. br; marcoskondo@unimontes.br

${ }^{2}$ Discentes da UNIMONTES, Janaúba, MG, Brasil. E-mail: rodrigoc.coutinho@yahoo.com.br; darioagronomia@hotmail.com

${ }^{3}$ Prof ${ }^{a}$ do Instituto Federal de Educação, Ciência e Tecnologia do Sul de Minas Gerais Machado, MG, Brasil. E-mail: neivavieira2003@yahoo.com.br

* Author for correspondence
} 
foram aproveitadas as quatro fileiras centrais, totalizando $10 \mathrm{~m}^{2}$ de área útil. Foram avaliados: estande final, número de vagens por planta, número de grãos por vagem, massa de 100 grãos e produtividade. As doses de $\mathrm{N}$ em semeadura proporcionaram incrementos no número de vagens por planta, e a adubação em cobertura, com 83,33 $\mathrm{kg} \mathrm{ha}^{-1}$ de $\mathrm{N}$, produziu a maior massa de 100 grãos. A produtividade máxima (MET-3.092 kg ha-1) foi observada com 62,4 $\mathrm{kg} \mathrm{ha}^{-1}$ de N em semeadura mais 61,9 kg ha-1 de $\mathrm{N}$ em cobertura, e a máxima eficiência econômica (MEE) com 60,3 kg ha ${ }^{-1}$ de $\mathrm{N}$ em semeadura mais $59,5 \mathrm{~kg}$ ha $^{-1}$ de $\mathrm{N}$ em cobertura, indicando a necessidade de parcelamento da adubação nitrogenada no período das águas para o feijoeiro comum cultivado no Norte do Estado Minas Gerais.

Palavras-chave: Phaseolus vulgaris L, massa de 100 grãos, produtividade

\section{Introduction}

The common bean has special importance in Brazil, given its relevance in the population's diet and because the country is one of the world's largest producers and consumers of beans (BARBOSA et al., 2010), although the national mean yield is only $935 \mathrm{~kg} \mathrm{ha}^{-1}$ (CONAB, 2012). The use of inadequate levels and inefficient split fertilization of nitrogen $(\mathrm{N})$ for the crop stand out among the factors related to this low yield.

Split $\mathrm{N}$ fertilization at seeding and sidedressing up to 21 days after emergence has enabled the best responses of the common bean in terms of increased yield. Accordingly, the recommendations of $\mathrm{N}$ fertilization for the State of Minas Gerais range from 40 to $100 \mathrm{~kg} \mathrm{ha}^{-1}$, with application of 20 to $40 \mathrm{~kg} \mathrm{ha}^{-1}$ at seeding and 20 to $60 \mathrm{~kg} \mathrm{ha}^{-1}$ at sidedressing from 20 to 30 days after emergence (DAE) (CHAGAS et al., 1999).

However, local climate variations, including excessive rainfall or water deficits, and increased soil temperature following fertilization with soluble sources of $\mathrm{N}$, including urea, cause an increase in the processes of soil $\mathrm{N}$ loss through leaching or volatilization. This loss results in production inefficiency and variations in the responses of bean crops to nitrogen fertilization. According to Sangoi, Santos and Silveira (2003), the very increase in N level in the form of urea results in increased soil $\mathrm{N}$ leaching due to increased $\mathrm{N}_{-} \mathrm{NO}_{3}^{-}$levels.

Positive responses and variations in the recommended levels of split nitrogen fertilization are found in the literature regarding the yield components of common bean. Silva and Silveira (2000) found a quadratic response of common bean to $\mathrm{N}$ fertilization at sidedressing, and the maximum yield was reached with $74 \mathrm{~kg} \mathrm{ha}^{-1}$ in a conventional tillage system. Soratto, Carvalho and Arf (2004) noted that the maximum yield of common bean in a conventional tillage system was reached using an estimated $\mathrm{N}$ level at sidedressing of $129 \mathrm{~kg} \mathrm{ha}^{-1}$, following maize cultivation.

Regarding the efficiency of split fertilization, Franco et al. (2008) reported identical responses of increased grain yield with split seeding and sidedressing fertilization or only seeding fertilization at an $\mathrm{N}$ level of $100 \mathrm{~kg} \mathrm{ha}^{-1}$. In addition, Binotti et al. (2009) concluded that the yield of irrigated common bean in the winter was not affected by the split, or not, of nitrogen fertilization, recommending fertilization with urea and ammonium sulfate at a single $\mathrm{N}$ level of $150 \mathrm{~kg} \mathrm{ha}^{-1}$. Such results were associated with a lower loss of soil $\mathrm{N}$ by leaching, given the lack of or lower rainfall in the growing seasons. However, Alvarez et al. (2005) found that sidedressing $\mathrm{N}$ fertilization via soil resulted in increased leaf $\mathrm{N}$ levels, number of grains per plant, 100 -grain weight and grain yield of common bean, even for doses above $100 \mathrm{~kg} \mathrm{ha}^{-1}$.

The occurrence of high rainfall in a short period of time combined with maximum daily temperatures above $30^{\circ} \mathrm{C}$, contributing to greater losses of soil $\mathrm{N}$ by leaching and volatilization $\left(\mathrm{N}-\mathrm{NH}_{3}\right)$, are common conditions of common bean growth during the rainy season in the northern region of Minas Gerais State. Coupled to these factors, only a few studies have been conducted on the effect of split $\mathrm{N}$ levels on 
bean production in the semiarid region of Minas Gerais. Thus, the present study aimed to assess the agronomic characteristics following fertilization with different $\mathrm{N}$ levels at seeding and sidedressing of common bean grown during the rainy season in Northern Minas Gerais.

\section{Materials and Methods}

The study was conducted at the Experimental Farm, State University of Montes Claros (Universidade Estadual de Montes Claros), located in the municipality of Janaúba, Minas Gerais, operated under conventional sprinkler irrigation. The experimental area is located $8 \mathrm{~km}$ from the city of Janaúba at $15^{\circ} 47^{\prime} 50$ 'S latitude, $43^{\circ} 18^{\prime} 31^{\prime \prime} \mathrm{W}$ longitude and 516-m altitude on a dystrophic Red Latosol (EMBRAPA, 2006). The climate is classified as Aw (tropical wet, savannah with dry winter), according to the Köppen classification.

The study was conducted during the rainy season using the 'Pérola' cultivar. Seeding began in February 2010, following soil preparation by plowing and harrowing. The soil chemical analysis was performed through sample collection at 0 to 20$\mathrm{cm}$ depth, corresponding to $\mathrm{pH}\left(\mathrm{H}_{2} \mathrm{O}\right)=5.2$, organic matter $=36.0 \mathrm{~g} \mathrm{~kg}^{-1}, \mathrm{P}=5.2 \mathrm{mg} \mathrm{dm}^{-3}, \mathrm{~K}=96.0 \mathrm{mg}$ $\mathrm{dm}^{-3}$ (Mehlich 1), $\mathrm{Al}^{3+}=0.1 \mathrm{cmol}_{\mathrm{c}} \mathrm{dm}^{-3}, \mathrm{Ca}^{2+}=2.6$ $\mathrm{cmol}_{\mathrm{c}} \mathrm{dm}^{-3}, \mathrm{Mg}^{2+}=0.5 \mathrm{cmol}_{\mathrm{c}} \mathrm{dm}^{-3}\left(\mathrm{KCl}-1 \mathrm{~mol} \mathrm{~L}^{-1}\right)$, $\mathrm{H}+\mathrm{Al}=2.10 \mathrm{cmol}_{\mathrm{c}} \mathrm{dm}^{-3}\left(0.5 \mathrm{~mol} \mathrm{~L}^{-1}\right.$ calcium acetate $-\mathrm{pH}$ 7.0) and remaining-P (P equilibrium solution) $=29.0 \mathrm{mg} \mathrm{L}^{-1}$. The experimental area had been used for successive crops of Brachiaria and sorghum under conventional sprinkler irrigation in the two years preceding the present study.

The recommended fertilization (except $\mathrm{N}$ ) and liming for the common bean crop was performed to reach yields greater than $2,500 \mathrm{~kg} \mathrm{ha}^{-1}$ (technological level $4\left[\mathrm{TL}_{4}\right]$ ), according to Chagas et al. (1999), and corresponded to levels of $20 \mathrm{~kg} \mathrm{ha}^{-1} \mathrm{~K}_{2} \mathrm{O}$ in the form of potassium chloride, $110 \mathrm{~kg} \mathrm{ha}^{-1} \mathrm{P}_{2} \mathrm{O}_{5}$ in the form of simple superphosphate, $1 \mathrm{~kg} \mathrm{ha}^{-1} \mathrm{~B}$, using boric acid as the source, and $60 \mathrm{~g} \mathrm{ha}^{-1} \mathrm{Mo}$ in the form of sodium molybdate, administered from 15 to 25 DAE. Liming was not necessary based on the results from the soil chemical analysis.

The average rainfall in the cultivation period (February to May) was $232 \mathrm{~mm}$ (Figure 1), the average temperature was $26.5{ }^{\circ} \mathrm{C}$, and the air relative humidity ranged from 56 to $71 \%$ (INMET, 2012). Irrigation was performed using conventional sprinklers with an average flow of 1,500 $\mathrm{L}_{\text {hour }}{ }^{1}$ and managed according to the natural rainfall in the cultivation period and the crop requirements $(\mathrm{Kc})$ during the development stages.

A randomized block design with three replicates in a $4 \times 4$ factorial scheme, involving four nitrogen levels at seeding $\left(0,40,80\right.$ and $\left.120 \mathrm{~kg} \mathrm{ha}^{-1}\right)$ and four nitrogen levels at sidedressing $(0,40,80$ and $120 \mathrm{~kg} \mathrm{ha}^{-1}$ ), was used. The nitrogen source was urea, incorporated into the soil at planting and 20 DAE, continuously applied in small furrows, approximately $2 \mathrm{~cm}$ deep, between rows and incorporated into the soil using a hoe, prior to irrigation.

Each plot consisted of six 5-m-long rows, spaced $0.5 \mathrm{~m}$ apart. The four central rows of each plot were used, totaling $10 \mathrm{~m}^{2}$ of useful area. Seeding was performed manually, seeding 14 seeds per linear meter, with an average population of 240,000 plants per hectare. The common bean development cycle, from seeding to grain harvest, lasted approximately 89 days, at which time the plants from the four central rows were harvested for the evaluation of the following parameters: final stand, number of pods per plant, number of grains per pod, 100-grain weight and yield. The yield was estimated based on the plot production, with a humidity correction to $13 \%$, including the plants selected for the evaluation of yield components. 
Figure 1. Rainfall (mm day $\left.{ }^{-1}\right)$ and maximum and minimum temperature $\left({ }^{\circ} \mathrm{C}\right)$ in Janaúba, MG, in 2010.

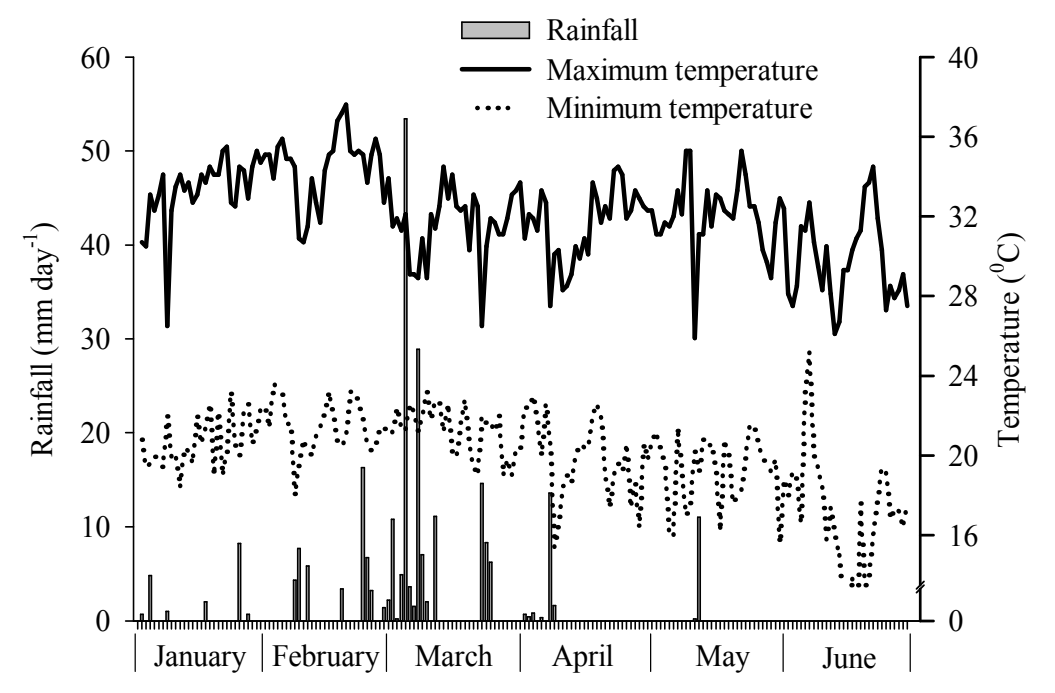

Source: INMET (2012).

The effects of $\mathrm{N}$ doses at seeding and sidedressing on the yield components were subjected to an analysis of variance at $5 \%$ significance, using the F-test, and when significant $(\mathrm{p}<0.05)$, the quantitative variables were adjusted by regression according to the biological performance and model significance.

The $\mathrm{N}$ level for maximum technical efficiency (MTE) considering the maximum physical yield was estimated based on the Gaussian mathematical model according to the following equation:

$$
\hat{y}=a e^{\left[-0,5\left(\frac{x-x_{0}}{b}\right)^{2}+\left(\frac{y-y_{0}}{c}\right)^{2}\right]}
$$

where

$\mathrm{a}=$ maximum grain yield value.

$\mathrm{x}_{0}=\mathrm{N}$ level at seeding for maximum yield.

$\mathrm{y}_{0}=\mathrm{N}$ level at sidedressing for maximum yield.

The partial net profit per hectare was initially estimated by multiplying the obtained yield by the estimated price of beans and subtracting the cost of the $\mathrm{N}$ fertilizer, according to the levels of $\mathrm{N}$ used, ignoring the value of the fixed costs for the common bean crop in this calculation, to assess the maximum economic efficiency (MEE):

$$
P=S Y-F
$$

where $\mathrm{P}$ is the partial net profit, $\mathrm{S}$ is the common bean sale price, corresponding to $2.48 \mathrm{R} \$ \mathrm{~kg}^{-1}$ (EMATER, 2012), $\mathrm{Y}$ is the yield as a function of $\mathrm{N}$ level, and $\mathrm{F}$ is the cost of fertilizer, corresponding to $2.02 \mathrm{RS} \mathrm{kg}^{-1}$ of $\mathrm{N}$. The partial net profit was subsequently adjusted to the Gaussian model to assess the $\mathrm{N}$ levels at seeding and sidedressing for MEE.

The agronomic efficiency of $\mathrm{N}$ (AEN) was estimated using the equation proposed by Baligar et al. (1990):

$$
A E N=\frac{(F Y-N F Y)}{Q N A}
$$

where FY is the fertilized bean yield $\left(\mathrm{kg} \mathrm{ha}^{-1}\right)$, NFY is the non-fertilized bean yield $\left(\mathrm{kg} \mathrm{ha}^{-1}\right)$, and QNA is the quantity of $\mathrm{N}$ applied $\left(\mathrm{kg} \mathrm{ha}^{-1}\right)$.

\section{Results and Discussion}

A significant interaction $(\mathrm{p}<0.05)$ between the $\mathrm{N}$ levels at seeding and $\mathrm{N}$ levels at sidedressing was noted for the yield based on the analysis of variance (Table 1). A significant effect of the $\mathrm{N}$ levels at 
seeding and 100-grain weight was observed as well as an effect of $\mathrm{N}$ levels at sidedressing in common bean for the parameters final stand and number of pods per plant (Table 1).

Table 1. Analysis of variance of the final stand (FS), 100-grain weight (GW), number of pods per plant (PP), number of grains per pod (GP) and yield (YIELD) of common bean grown during the rainy season following fertilization with different $\mathrm{N}$ levels at seeding and sidedressing.

\begin{tabular}{lcrrrrr}
\hline \multirow{2}{*}{ Fixed Variable } & \multirow{2}{*}{ GL } & \multicolumn{5}{c}{ QM } \\
\cline { 3 - 6 } & & FS & GW & PP & GP & \multicolumn{1}{c}{ YIELD } \\
\hline N-Seed (Seed) & 3 & $1,680,000,000.00^{*}$ & $5.13^{\text {ns }}$ & $37.71^{*}$ & $0.07^{\text {ns }}$ & $2,127,141.13^{*}$ \\
N-Side (Side) & 3 & $356,000,000.00^{\text {ns }}$ & $16.57^{*}$ & $6.98^{\text {ns }}$ & $0.30^{\text {ns }}$ & $1,067,020.40^{\text {ns }}$ \\
Seed versus Side & 9 & $87,500,000.00^{\text {ns }}$ & $3.96^{\text {ns }}$ & $13.56^{\text {ns }}$ & $0.40^{\text {ns }}$ & $1,847,178.57^{* *}$ \\
Residue & 30 & $177,662,847.00$ & 2.11 & 7.71 & 0.19 & $731,522.00$ \\
Mean & & $151,281.00$ & 31.72 & 14.65 & 5.48 & $2,295.00$ \\
CV $(\%)$ & 9.00 & 4.58 & 18.97 & 8.08 & 37.26 \\
\hline
\end{tabular}

**, *, ns: significant at 1\%, significant at 5\% and non-significant using the F-test, respectively.

Source: Elaboration of the authors.

The application of different $\mathrm{N}$ levels at seeding resulted in a quadratic effect on the final stand of plants, and the seeding levels of $50.88 \mathrm{~kg} \mathrm{ha}^{-1}$ and $120 \mathrm{~kg} \mathrm{ha}^{-1}$ accounted for the highest $(162,472.39$ plants or 8.12 plants $\mathrm{m}^{-1}$ ) and lowest (135.250 plants or 6.76 plants $\mathrm{m}^{-1}$ ) plant population or density of the common bean crop, respectively (Figure 2A). The reduction in the final stand of plants upon fertilization with the highest $\mathrm{N}$ level at seeding can be explained by the urea salt effect on plants at early stages of germination and development. According to Gheyi (2000), salinity can affect germination, not only hindering the water absorption by seeds but also facilitating the entry of ions at toxic concentrations characterized by the accumulation of specific ions in the plant.

The mean number of pods per plant showed a quadratic response to increasing $\mathrm{N}$ levels at seeding; 13.00 pods plant $^{-1}$ were noted at the initial $\mathrm{N}$ level (zero), and approximately 17.16 pods plant $^{-1}$ were found at the level of $120 \mathrm{~kg} \mathrm{ha}^{-1}$ (Figure 2B). Although a decrease in the final stand was noted at the level of $120 \mathrm{~kg} \mathrm{ha}^{-1}$, this decrease did not lead to a decrease in the number of pods plant ${ }^{-1}$ at this level, which shows the phenotypic plasticity of the common bean and its compensatory effect in regard to the primary yield components. According to Silva et al. (2009), the increases in pods per plant with increasing levels of $\mathrm{N}$ may occur as a result of higher plant height and increased production of reproductive branches. Thus, the highest level could have been a determinant of the increased plant height and production of reproductive branches, thereby generating an increase in the number of pods plant ${ }^{-1}$ (MEIRA et al., 2005; BINOTTI et al., 2010).

The application of different $\mathrm{N}$ levels at sidedressing enabled a quadratic effect on the 100 -grain weight, and an increase in the 100-grain weight was observed up to a level of $83.33 \mathrm{~kg} \mathrm{ha}^{-1}$ $\mathrm{N}$, with an estimated weight of $32.29 \mathrm{~g}$ (Figure 2C). Teixeira et al. (2000) also found an increase in the 100 -grain weight up to a level of $77.36 \mathrm{~kg} \mathrm{ha}^{-1} \mathrm{~N}$, with an estimated weight of $28.50 \mathrm{~g}$. Such an effect may be associated with the roles of $\mathrm{N}$ in common bean because $\mathrm{N}$ is the basic constituent of amino acids, bean seeds are approximately $25 \%$ protein, and the $\mathrm{N}$ supply at the proper level leads to greater protein production (GOMES JUNIOR et al., 2005) and, therefore, higher 100-grain weight. 
Figure 2. Final stand of plants, number of pods per plant and 100-grain weight of plants subjected to $\mathrm{N}$ levels at seeding (A and B) and at sidedressing (C) in common bean grown during the rainy season. Janaúba - MG, 2010.
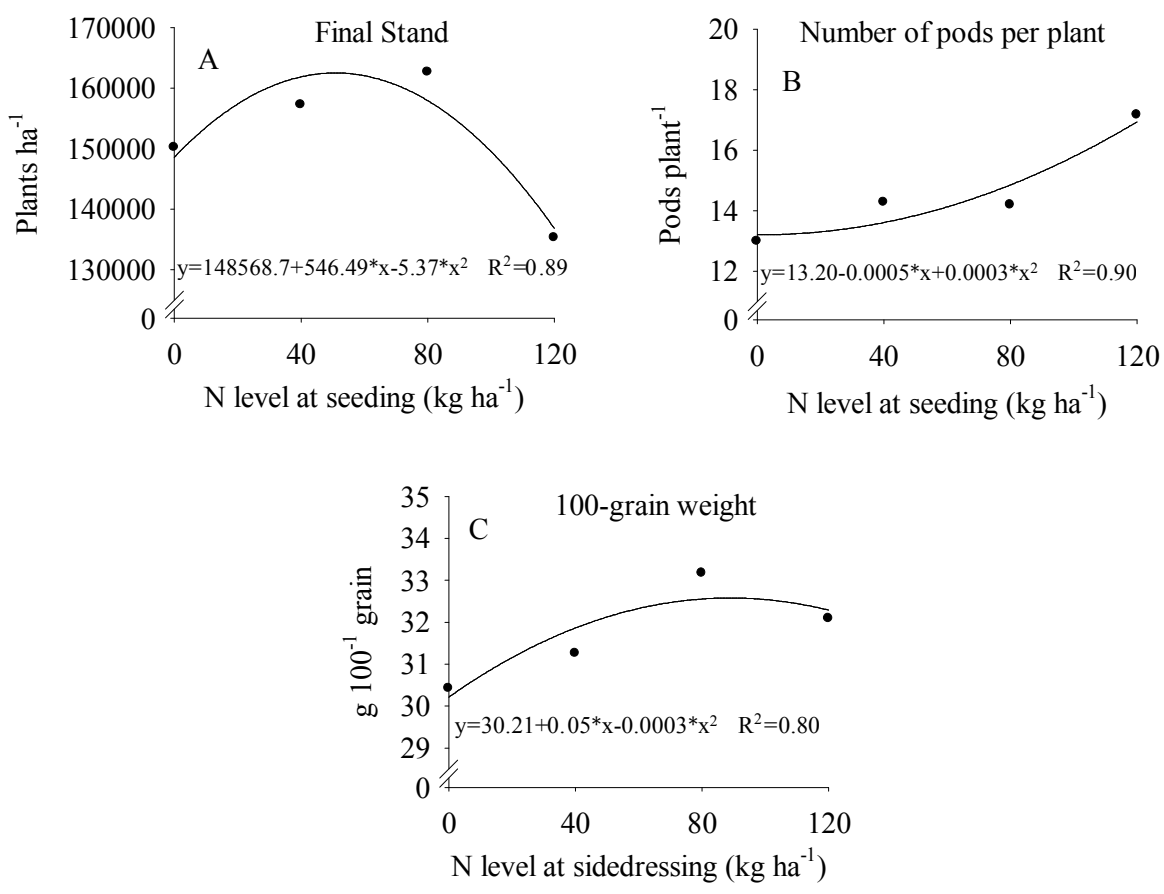

Source: Elaboration of the authors.

The common bean yield was affected by the $\mathrm{N}$ levels at seeding and sidedressing (Figure 3). The level of maximum technical efficiency (MTE), corresponding to 62.4 and $61.9 \mathrm{~kg} \mathrm{ha}^{-1} \mathrm{~N}$ at seeding and sidedressing, respectively (Table 2), was found after fitting the Gaussian model of the response surface. This application totals a recommended level of $124 \mathrm{~kg} \mathrm{ha}^{-1} \mathrm{~N}$ for a 3,092 $\mathrm{kg} \mathrm{ha}^{-1}$ common bean yield. This result was higher than the level recommended by Chagas et al. (1999), who suggested the application of $40 \mathrm{~kg} \mathrm{ha}^{-1}$ at seeding and $60 \mathrm{~kg} \mathrm{ha}^{-1} \mathrm{~N}$ at sidedressing to reach a grain yield above $2.500 \mathrm{~kg} \mathrm{ha}^{-1}$. However, Meira et al. (2005) found the maximum yield in their study using a level of $160 \mathrm{~kg} \mathrm{ha}^{-1} \mathrm{~N}$, which produced $3.639 \mathrm{~kg}$ grain ha-1 ${ }^{-1}$ applied in $\mathrm{N}$ levels of $0,40,80,120,160$, 200 and $240 \mathrm{~kg} \mathrm{ha}^{-1}$ at sidedressing, and Kikuti et al. (2005) found that the maximum yield was obtained when growing the BRS MG Talismã variety during the rainy season with a level of $124.3 \mathrm{~kg} \mathrm{ha}^{-1} \mathrm{~N}$.

Table 2. Yield and recommended levels of $\mathrm{N}$ for maximum technical efficiency (MTE) and maximum economic efficiency (MEE) of common bean grown during the rainy season following fertilization with different $\mathrm{N}$ levels at seeding versus increasing $\mathrm{N}$ levels at sidedressing. Janaúba - MG, 2010.

\begin{tabular}{lcc}
\hline \multicolumn{1}{c}{ Recommendations } & MTE & MEE \\
\hline Yield & $3,091.62 \mathrm{~kg} \mathrm{ha}^{-1}$ & $7,420.98 \mathrm{R}^{\text {h ha }} \mathrm{ga}^{-1 \#}$ \\
$\mathrm{~N}$ level at seeding $\left(\mathrm{kg} \mathrm{ha}^{-1}\right)$ & 62.42 & 60.32 \\
$\mathrm{~N}$ level at sidedressing $\left(\mathrm{kg} \mathrm{ha}^{-1}\right)$ & 61.92 & 59.49 \\
Total N level $\left(\mathrm{kg} \mathrm{h}^{-1}\right)$ & 124.34 & 119.81 \\
Agronomic efficiency of N $\left(\mathrm{kg} \mathrm{kg}^{-1}\right)$ & 12.56 & 12.33 \\
\hline
\end{tabular}

\#: Minimum price per bag $\left(60 \mathrm{~kg}\right.$ ) of Carioca bean paid to producers in September 2012, equivalent to $2.48 \mathrm{R} \$ \mathrm{~kg}^{-1}$, and the price of fertilizer (urea), corresponding to $2.02 \mathrm{RS} \mathrm{kg}^{-1} \mathrm{~N}$, were used to calculate the partial net profit.

Source: Elaboration of the authors. 
The cultivation season (rainy season) and $\mathrm{N}$ nutritional demand by common bean plants are among the main factors responsible for the increase in grain yield, with increasing $\mathrm{N}$ levels at seeding and sidedressing split fertilization totaling the recommended level of $124 \mathrm{~kg} \mathrm{ha}^{-1}$. As indicated in Figure 1, high rainfall was recorded at specific days during the initial period of common bean development, between the months of February and March, resulting in possible soil $\mathrm{N}$ loss by leaching, enabling the use of higher $\mathrm{N}$ levels and the balanced split of seeding and sidedressing fertilization to increase the yield.

Another important factor to be considered in the management of nitrogen fertilization is the growing demand of the common bean for nitrogen during its vegetative development. It is therefore important to maintain a high availability of mineral $\mathrm{N}$ in the soil through sidedressing fertilization in the first 30 DAE.

The plant characteristics that noticeably contributed most toward increasing the yield were the number of pods per plant and the 100-grain weight of common bean following seeding and sidedressing nitrogen fertilization. The proper plant nutrition with $\mathrm{N}$ most likely enabled the increase in plant leaf area, which increases the efficiency of interception of solar radiation, the photosynthetic rate (FAGERIA; BALIGAR, 2005) and, consequently, the number of pods per plant, 100 -grain weight and grain yield of the common bean.
The levels corresponding to the maximum economic efficiency (MEE) were also fitted using the Gaussian model of the response surface (Figure 3) and corresponded to 60.3 and $59.5 \mathrm{~kg} \mathrm{ha}^{-1} \mathrm{~N}$ at seeding and sidedressing (Table 2), respectively, totaling the recommended level of $120 \mathrm{~kg} \mathrm{ha}^{-1} \mathrm{~N}$, for a partial net profit of 7,420.98R $\$ \mathrm{ha}^{-1}$ when deducting only the amount spent on $\mathrm{N}$ fertilizer and disregarding the crop's fixed cost. The use of this fitted model for obtaining the $\mathrm{N}$ levels to produce the MEE is warranted by the high market price of the common bean in recent years.

The maximum efficiency of $\mathrm{N}$ utilization resulted from levels of 42.94 and $31.97 \mathrm{~kg} \mathrm{ha}^{-1} \mathrm{~N}$ at seeding and sidedressing, respectively (Figure 3), and corresponded to $23.54 \mathrm{~kg}$ grains produced per $\mathrm{kg}$ of $\mathrm{N}$ fertilizer. Accordingly, the highest efficiency of $\mathrm{N}$ utilization in the common bean crop was noted at levels below the recommended levels for MTE and MEE. The efficiency of $\mathrm{N}$ utilization for MTE and MEE was assessed as between 12 and $13 \mathrm{~kg}$ grains produced per $\mathrm{kg}$ of $\mathrm{N}$ fertilizer (Table 2). Such results corroborate those found by Sant'ana, Santos and Silveira (2011), who noted a decrease in the agronomic efficiency of $\mathrm{N}$ with higher levels of $\mathrm{N}$ fertilization and a mean efficiency of $16 \mathrm{~kg}$ $\mathrm{kg}^{-1}$. Noticeably, the highest agronomic efficiency of $\mathrm{N}$ in most growth conditions does not correspond to the point of maximum grain accumulation or production of the common bean because there is a decreasing $\mathrm{N}$ demand by the crop as the growth responses approach the maximum genetic potential of the crop. 
Figure 3. Yield, partial net profit and agronomic efficiency of $\mathrm{N}$ following fertilization with different $\mathrm{N}$ levels at seeding and sidedressing in common bean grown during the rainy season. Janaúba - MG, 2010.

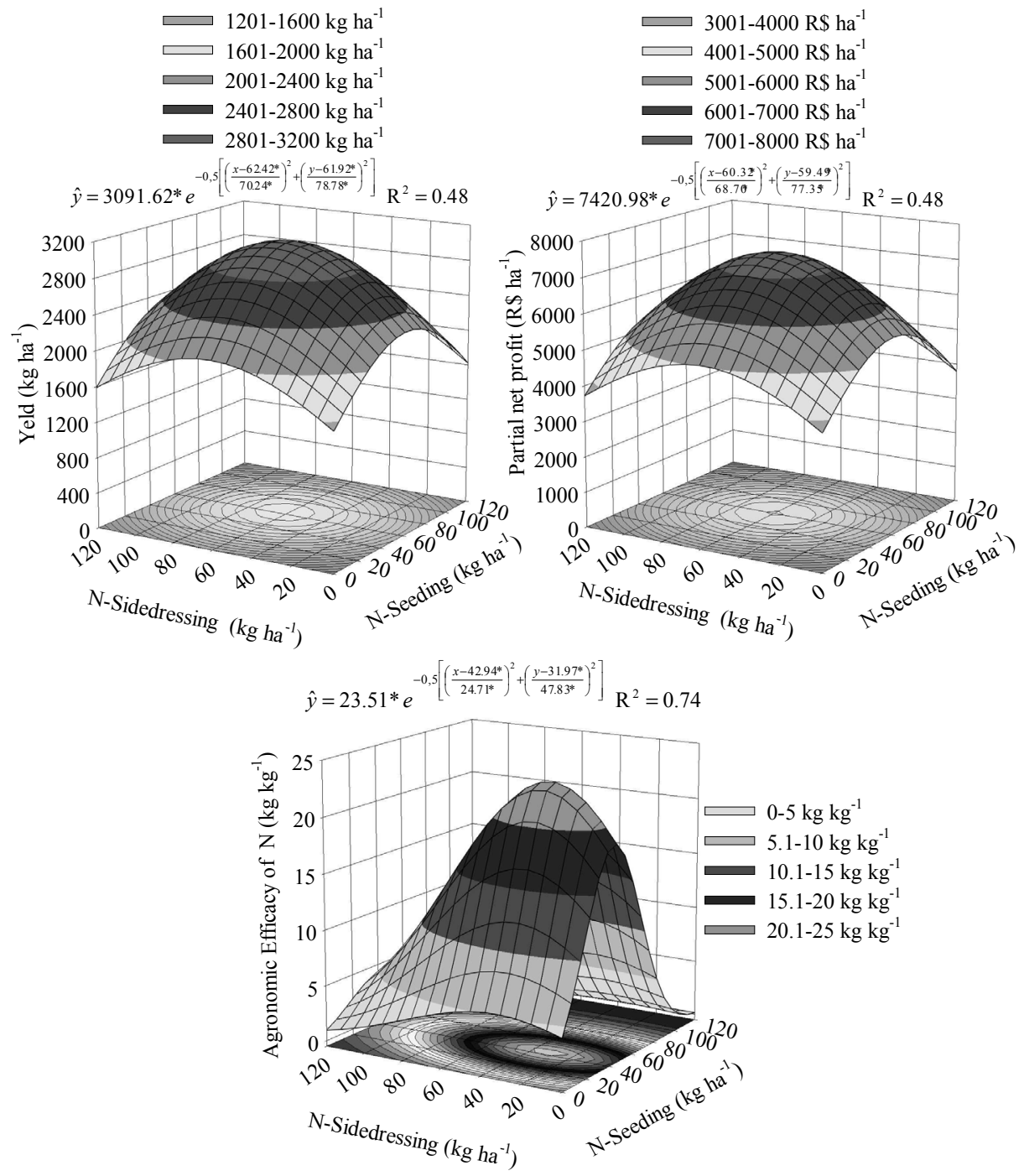

Source: Elaboration of the authors.

\section{Conclusions}

The $\mathrm{N}$ level of $50.88 \mathrm{~kg} \mathrm{ha}^{-1}$ at seeding enabled the maximum final stand of plants.

The application of $\mathrm{N}$ at seeding increased the number of pods per plant, and the increased $\mathrm{N}$ levels at sidedressing increased the 100 -grain weight.

The maximum yield of common bean $(3.092 \mathrm{~kg}$ $\mathrm{ha}^{-1}$ ) was found when using $62.4 \mathrm{~kg} \mathrm{ha}^{-1} \mathrm{~N}$ at seeding and $61.9 \mathrm{~kg} \mathrm{ha}^{-1} \mathrm{~N}$ at sidedressing.
The maximum economic efficiency of common bean grown during the rainy season was found when using $60.3 \mathrm{~kg} \mathrm{ha}^{-1} \mathrm{~N}$ at seeding and $59.5 \mathrm{~kg} \mathrm{ha}^{-1} \mathrm{~N}$ at sidedressing.

\section{Acknowledgments}

The authors thank the FAPEMIG (Fundação de Amparo à Pesquisa do estado de Minas Gerais / Minas Gerais State Research Foundation) 
for funding the research project and granting the Scholarship for Incentive to Research and Technological Development (Bolsa de Incentivo a Pesquisa e ao Desenvolvimento Tecnológico BIPDT) to the professors involved.

\section{References}

ALVAREZ, A. C. C.; ARF, O.; ALVAREZ, R. C. F.; PEREIRA, J. C. R. Response of the bean plant to the application of rates and sources of side-dressing nitrogen in a no-tillage system. Acta Scientiarum. Agronomy, Maringá, v. 27, n. 1, p. 69-75, 2005.

BALIGAR, V. C.; BALIGAR, V. C.; DUNCAN, R. R.; FAGERIA, N. K. Soil-plant interaction on nutrient efficiency in plants: an overview. In: BALIGAR, V. C.; DUNCAN, R. R. (Ed.). Crops as enhancers of nutrient use. San Diego: Academic, 1990. p. 351-373.

BARBOSA, G. F.; ARF, O.; BUZETTI, S.; FREDDI, O. S. Nitrogen sidedressing and molybdenum leaf application on irrigated common bean in cerrado soil. Acta Scientiarum. Agronomy, Maringá, v. 32, n. 1, p. 117-123, 2010.

BINOTTI, F. F. S.; ARF, O.; SÁ, M. E.; BUZETTI, S.; ALVAREZ, A. C. C.; KAMIMURA, K. M. Effect of sources, levels and nitrogen split in winter common bean in a no-tillage system. Bragantia, Campinas, v. 68, n. 2, p. 473-481, 2009.

BINOTTI, F. F. S.; ARF, O.; CARDOSO, E. D.; SÁ, M. E.; BUZETTI, S.; NASCIMENTO, V. Sources and levels of sidedressing nitrogen on irrigated common bean cropped in winter in a no-tillage system. Bioscience Journal, Uberlândia, v. 26, n. 5, p. 770-778, 2010.

CHAGAS, J. M.; BRAGA, J. M.; VIEIRA, C.; SALGADO, L. T.; JUNQUEIRANETO, A.; ARAÚJO, G. A. A.; ANDRADE, M. J. B.; LANA, R. M. Q.; RIBEIRO, A. C. Feijão. In: RIBEIRO, A. C.; GUMIMARAES, P. T. G.; ALVAREZ V., V. H. Recommendations for the use of lime and fertilizers in Minas Gerais. $5^{\text {th }}$ ed. Viçosa: CFSEMG, 1999. p. 306-307.

COMPANHIA NACIONAL DE ABASTECIMENTO - CONAB. Brazilian harvest monitoring: grain: crop 2011/2012 - Eighth assessment - may/2012. 2012. 36 p.

EMPRESA BRASILEIRA DE PESQUISA AGROPECUÁRIA - EMBRAPA. Centro Nacional de Pesquisa de Solos. National research center for soils. Brazilian system of soil classification. 2. ed. Rio de Janeiro: Embrapa, 2006. 306 p.
EMPRESA DE ASSISTÊNCIA TÉCNICA E EXTENSÃO RURAL DO ESTADO DE MINAS GERAIS - EMATER/MG. Quarterly newsletter No. 90. Belo Horizonte, 2012. Available at: <http://www.emater. mg.gov.br/doc/intranet/upload/ciagro/inf.\%20conj.\%20 setembro\%202012.pdf $>$. Accessed on: 10 oct. 2012.

FAGERIA, N. K.; BALIGAR, V. C. Enhancing nitrogen use efficiency in crop plants. Advances in Agronomy, Newark, v. 88, n. 4, p. $97-185,2005$.

FRANCO, E.; ANDRADE, C. A. B.; SCAPIM, C. A.; FREITAS, P. S. L. Response of the common bean to nitrogen application at seeding and sidedressing in nontillage systems. Acta Scientiarum. Agronomy, Maringá, v. 30, n. 3, p. 427-434, 2008.

GHEYI, H. R. Problemas de salinidade na agricultura irrigada [Salinity problems in irrigated agriculture]. In: OLIVEIRA, T. S.; ASSIS, R. N.; ROMERO, R. E.; SILVA, J. R. C. (Ed.). Agriculture, sustainability and the semi-arid. Fortaleza: DCS/UFC, 2000. p. 329-346.

GOMES JUNIOR, F. G.; LIMA, E. R.; LEAL, A. J. F.; MATOS, F. A.; SÁ, M. E.; HAGA, K. I. Protein contents in common bean grains in different nitrogen-sidedressing times and rates. Acta Scientiarum. Agronomy, Maringá, v. 27, n. 3, p. $455-459,2005$.

BRAZILIAN NATIONAL INSTITUTE OF METEOROLOGY. Meteorological database for teaching and research. Available at: $<\mathrm{http}: / / \mathrm{www}$.inmet. gov.br/portal/index.php? $r=$ bdmep/bdmep $>$. Accessed on: 29 sept. 2012.

KIKUTI, H.; KIKUTI, H.; ANDRADE, M. J. B.; CARVALHO, J. G.; MORAIS, A. R. Nitrogen and phosphorus in the cultivated bean variety BRS MG Talismã (Phaseolus vulgaris L.). Acta Scientiarum. Agronomy, Maringá, v. 27, n. 3, p. 415-422, 2005.

MEIRA, F. A.; SÁ, M. E.; BUZETTI, S.; ARF, O. Levels and time of nitrogen top-dressed application for common bean in a no-till system. Pesquisa Agropecuária Brasileira, Brasília, v. 40, n. 4, p. 383-388, 2005.

SANGOI, L.; SANTOS, A. B.; SILVEIRA, P. M. Volatilization of $\mathrm{N}^{-\mathrm{NH}_{3}}$ influenced by urea application forms, residue management and soil type in laboratory conditions. Ciência Rural, Santa Maria, v. 33, n. 4, p. 87-692, 2003.

SANT'ANA, E. V. P.; SANTOS, A. B.; SILVEIRA, P. M. The efficiency of use of nitrogen applied in top dressing in irrigated beans. Revista Brasileira de Engenharia Agrícola e Ambiental, Campina Grande, v. 15, n. 5, p. 458-462, 2011. 
SILVA, C. C.; SILVEIRA, P. M. Different agricultural systems and their effects on irrigated common bean (Phaseolus vulgaris $\mathrm{L}$.) response to nitrogen sidedressing. Pesquisa Agropecuária Tropical, Goiânia, v. 30, n. 1, p. 86-96, 2000.

SILVA, E. F.; MARCHETTI, M. E.; SOUZA, L. C. F.; MERCANTE, F. M.; RODRIGUES, E. T.; VITORINO, A.

C. T. Innoculation effect of Rhizobium tropici associated with Mimosa flocculosa exudates on bean plants under different nitrogen rates. Bragantia, Campinas, v. 68, n. 2 , p. 443-451, 2009.
SORATTO, R. P.; CARVALHO, M. A. C.; ARF, O. Chlorophyll content and grain yield of common bean as affected by nitrogen fertilization. Pesquisa Agropecuária Brasileira, Brasília, v. 39, n. 9, p. 895-901, 2004.

TEIXEIRA, I. R.; ANDRADE, M. J. B.; CARVALHO, J. G.; MORAIS, A. R.; CORREAA, J. B. D. Common bean (Phaseolus vulgaris L. cv. Pearl) response at different seeding densities and nitrogen levels. Revista Ciência e Agrotecnologia, Lavras, v. 24, n. 2, p. 399-408, 2000. 